\title{
KERAJINAN RUMAH TANGGA DI TANAH TORAJA Suatu Studi Mengenai Peranan Kerajinan Ukir-Ukiran Khas Toraja dalam Peningkat- an Taraf Kesejahteraan Hidup Pengrajin OLEH : PAT. BADRUN
}

I

Di dalam rumusan GBHN, kerajinan rumahtangga digolongkan ke dalam industri kecil. Pembinaannya telah diprogramkan sejak awal Repelita dan dalam Pelita V ini arah pembinaannya ditujukan kepada upaya memperluas lapangan pekerjaan serta kesempatan berusaha, meningkatkan ekspor, menumbuhkan kemampuan dan kemandirian berusaha serta meningkatkan pendapatan pengusaha kecil dan pengrajin.

Namun demikian, masih diprtanyakan seberapa jauh arah pembinaan yang akan dituju itu telah dapat tercapai, baik dalam skala nasional maupun daerah, terutama kontribusinya dalam meningkatkan tarap kesejahteraan hidup para pengrajin itu sendiri yang pada umumnya bermukim di pedesaan.

Informasi mengenai tingkat kesejahteraan hidup pengrajin, terutama mereka yang berada di pedesaan menekuni usaha kerajinan rumahtangga yang bersifat tradisionil perlu ditelusuri untuk keperluan evaluasi dalam rangka upaya pembinaan sesuai arah dan tujuan yang telah dirumuskan di dalam GBHN. Untuk keperluan itulah antara lain maka penelitian

" ini dirancang dan dilaksanakan, walaupun hanya dalam skala mikro.

Dalam penelitian ini, masalah kesejahteraan hidup yang diamati (dalam kaitan dengan obyek pengamatan yakni pengrajin atau pengusaha kerajinan rumahtangga) dibatasi dalam tiga bidang yakni bidang, ekonomi, bidang sosial, dan bidang keagamaan. Permasalahannya ialah seberapa jauh peranan usaha kerjainan rumah tangga dalam memberikan kontribusi terhadap peningkatan tarap kesejahteraan hidup para pengrajin itu sendiri dalam bidang-bidang ekonomi, sosial dan keagamaan.

Sesuai dengan permasalahan pokok maka penelitian ini diarahkan untuk memperoleh data dan informasi otentik mengenai hal-hal yang berkaitan dengan bidang-bidang kesejahteraan hidup yang diamati. Selain itu, informasi mengenai usaha kerajinan rumahtangga itu sendiri sebagai unit ekonomi industri juga turut dihimpun. Berdasarkan informasi itu dan informasi lain yang dianggap relevan/terkait, kemudian dilakukan pembahasan dengan tujuan menformulasikan wujud peranan usaha kerajinan rumahtangga dalam memberikan sumbangan terhadap peningkatan tarap kesejahteraan hidup para pengrajin khususnya dan masyarakat lingkungan pada umumnya.

\section{II}

Dengan mengacu kepada rumusan masalah dan tujuan penelitian maka aspek-aspek yang diamati dalam penelitian ini difokuskan pada tiga hal pokok, yakni : (1) Peranan usaha kerajinan rumahtangga selaku kegiatan ekonomi rumahtangga, (2) Peranan usaha kerajinan rumahtangga dalam kegiatan sosial serta ke- 
giatan pembangunan di lingkungan masyarakatnya, dan (3) Peranan usaha kerajinan rumahtangga dalam kegiatan keagamaan masyarakat lingkungannya. Ketiga aspek pokok inilah yang dalam penelitian ini diformulasikan sebagai variabel penelitian.

Penelitian dilaksanakan di daerah Kabupaten Tana Toraja dengan memilih secara purposive Kelurahan Tikunna Malenong (dalam Wilayah Kecamatan Sanggalangi) sebagai lokasi contoh dengan pertimbangan utama bahwa penduduk kelurahan ini banyak yang menekuni jenis kerajinan rumah tangga yang menjadi sasaran studi yakni kerajinan ukir-ukiran khas Toraja.

Kepada sejumlah informan utama yang terdiri dari para pengrajin ukir-ukiran khas Toraja telah dilakukan wawancara mendalam mengenai hal-hal yang berkaitan dengan aspekaspek yang diamati. Hasil analisis (kualitatiO terhadap data/informasi utama, setelah dilengkapi dengan informasi lain yang menunjang, kemudian digunakan untuk menjawab permasalahan pokok penelitian.

\section{III}

A. Kabupaten Tanah Toraja adalah salah satu daerah kabupaten di Sulawesi Selatan yang kaya dengan potensi usaha kerajinan rumah tangga. Usaha-usaha tersebut tumbuh dan berkembang secara turun-temurun serta eksistensinya ditopang oleh latar belakang sosial budaya masyarakat setempat. Nilai seninya yang khas serta sarat dengan kandungan makna simbolis menarik perhatian para wisatawan, terutama wisatawan asing sehingga industri kerajinan rumahtangga di daerah ini memiliki peranan penting dalam menunjang sektor pariwisata yang sementara digalakkan pengembangannya di daerah ini.
Jenis-jenis usaha kerajinan rumah tangga yang ditekuni masyarakat pengrajin di Tanah Toraja hingga dewasa ini adalah ukir-ukiran kayu dan bambu (ukir-ukiran khas Toraja), anyam-anyaman bambu dan rumput-rumputan, kain tenun adat, pembuatan parang dan keramik yang semuanya berciri khas Toraja. Jumlah unit usaha yang terdaftar dalam tahun 1988 adalah 2.068 unit, terdiri dari 30 sentra dari 9 jenis tersebar, terbesar pada 26 kelurahan/desa dari 8 kecamatan. Jumlah ini belum termasuk unit usaha yang tidak/belum mendaftarkan diri. Jumlah tenaga kerja yang diserap ke dalam 2.068 unit usaha berjumlah 5.742 orang, diantaranya 780 orang yang diserap ke dalam 291 unit usaha kerajinan ukirukiran.

Khusus di Kelurahan Tikunna Malenong (lokasi contoh) yang berpenduduk 9.767 jiwa (rata-rata 370 jiwa setiap kilometer persegi) dan 1.859 rumahtangga, tidak kurang dari 600 rumahtangga menekuni usaha kerajinan ukirukiran namun yang tergabung dalam sentra baru 191 unit.

Ukir-ukiran khas Toraja, tidak sekedar sebagai ragam hias semata yang mengutamakan nilai estetisnya, tetapi secara keseluruhan ukirukiran khas Toraja merupakan simbol dokumentasi perkembangan sejarah dan kebudayaan Toraja yang sarat dengan kandungan makna yang secara garis besar melambangkan empat tugas pokok manusia sekaligus sebagai dasar susunan dan kehidupan masyarakat Toraja. Keempat tugas pokok yang dimaksud ialah : (1) Mengenai adanya dan menyembah Sang Pencipta, (2) Mengenai dan menerapkan hukum dalam kehidupan masyarakat, (3) Bekerja keras untuk memenuhi kebutuhan hidup, dan (4) Mengenai serta menerapkan tata hubungan sosial dan kemasyarakatan demi terpeliharanya

No. 1 \& 2 Thn. I Juli / Desember 1990 
kerukunan dan persatuan dalam masyarakat.

Dengan ukir-ukiran yang ditopang oleh penuturan, orang Toraja secara turun-temurun mampu memelihara dan melestarikan orisinali tas nilai-nilai budaya warisan leluhur mereka. Lewat ratusan (tidak kurang 150) macam ragam dan motif ukir-ukiran yang berciri pokok geometris dengan suguhan gambar-gambar berwarna terang dan bergaya dekoratif dalam pola yang menampakkan keutuhan, orang Toraja ingin memperkenalkan falsafah hidup dan sistem sosial mereka yang mengutamakan keutuhan dan persatuan serta kebersamaan dalam ikatan norma dan hukum yang jelas.

Di antara manifestasinya yang jelas terlihat dalam kehidupan masyarakat ialah solidaritas etnis, gotong-royong sosial dan kerukunan antar umat beragama.

B. Kondisi usaha kerajian ukir-ukiran khas Tana Toraja dcwasa ini, sebagai unit ekonomi industri rumahtangga, secara umum tidak berbeda dengan kondisi jenis-jenis kerajinan (tradisional) lainnya yang ada di Tana Toraja.

Sebagaimana diindentifikasikan oleh Kantor Departemen Perindustrian Kabupaten Tana Toraja bahwa industri kerajinan rumah tangga di daerah ini pada umumnya memiliki kelemahan-kelemahan dalam hal permodalan, peralatan, tenaga kerja, kualitas produksi, dan pemasaran.

Kelemahan dalam permodalan ditandai dengan masih sangatkecilnya investasi (khusus kerajinan ukir-ukiran investasi setiap unit usaha hanya rata-rata Rp. 30.000,-), kelemahan dalam hal peralatan produksi ditandai dengan penggunaan peralatan tradisionil buatan lokal. Kelemahan dalam hal tenaga kerja ditandai dengan penggunaan tenaga kerja yang hanya memiliki ketrampilan alami yang diperoleh lewat sistem pewarisan dan dimatangkan melalui pengalaman.

No. 1 \& 2 Thn. I Juli / Desember 1990
Kelemahan dalam hal kualitas produksi ditandai dengan rendahnya mutu produksi sebagai akibat dari penggunaan bahan baku yang bermutu rendah. Sedangkan kelemahan dalam hal pemasaran ditandai dengan terbatasnya jangkauan pemasaran di mana produksi pada umumnya hanya dijual di daerah sendiri (daerah Tana Toraja) dan sebagian besar didominasi pedagang perantara yang cenderung berpraktek sama dengan tengkulak.

Namun demikian, kelemahan-kelemahan yang diidentifikasi dimiliki usaha kerajinan ukir-ukiran khas Toraja, sebagaimana dikemukakan di atas, pada sisi lain justru memberikan peluang kepada usaha ini untuk mampu mempertahankan eksistensinya serta tetap dapat menyumbangkan peranan-peranan sosialnya.

Peranan-peranan sosial yang dimaksudkan antara lain penyediaan lapangan berusaha serta penyerapan tenaga kerja (karena tidak disyaratkan harus didukung oleh investasi modal yang besar maka terbuka peluang bagi setiap anggota masyarakat yang berminat untuk mengusahakannya; demikian pula karena tidak dituntut keharusan menggunakan tenaga kerja yang trampil teknis maka setiap angkata kerja berpeluang untuk dapat diserap ke dalam proses produksi).

Kualitas produksi yang dianggap rendah (karena bahan baku yang digunakan rendah mutunya namun cukup tersedia di dalam daerah sendiri) memberikan peluang kepada kuantitas produksi yang relatif memenuhi kebutuhan konsumen, terutama wisatawan asing yang pada umumnya lebih tertarik kepada makna yang disimbolkan oleh suatu bentuk dan motif produk ukiran daripada kualitas fisiknya.

Keterbatasan jangkauan pemasaran hasil produksi (pada umumnya hanya di dalam daerah Tana Toraja saja) di satu pihak me- 
ngurangi/memperkecil biaya distribusi dan di lain pihak dapat merangsang kegairahan wisatawan untuk berkunjung ke daerah Tana Toraja dan dapat membeli langsung ukir-ukiran khas Toraja sebagai cendera mata. Sementara itu distribusi dan pemasaran lewat perantara, walaupun cara ini cenderung merupakan cara tengkulak, namun memberikan peluang cepatnya hasil produksi laku terjual hal mana memungkinkan setiap pengrajin dapat memanfaatkan langsung nilai tambah yang diperoleh dari hasil produksinya untuk pemenuhan kebutuhan sehari-hari yang mendesak.

Hal lain yang dapat diidentifikasikan sebagai faktor pendukung atau pilar-pilar penopang utama tetap bertahannya usaha kerajinan ukir-ukiran Tana Toraja, sebagaimana terungkap lewat penelitian ini, ialah adanya semacam "potensi etos" yang dimiliki para pengrajin. Potensi etos yang dimaksudkan yakni: (1) Kepercayaan kuat masyarakat (orang) Toraja akan keluhuran nilai-nilai yang disimbolkan oleh ragam ukiran dan karena itu mereka tetap menginginkan kelangsungan hidup usaha kerajinan ini, dan berbarengan dengan itu dikalangan para pengrajin sendiri (2) muncul semangat kreativitas untuk meramu ragam dan motif ukiran mereka dengan kreasi-kreasi baru, dan (3) dimilikinya semangat kemandirian yang kuat walaupun dalam kondisi yang serba sederhana.

Dapat disimpulkan bahwa kelemahan yang diidentifikasi dimiliki usaha kerajinan ukirukiran khas Toraja (bila dilihat sebagai unit ekonomi industri) justru dirasakan oleh para pengrajin sendiri sebagai peluang untuk mampu tetap eksist dan memberikan peranan-peranan sosial di dalam lingkungan masyarakat sekitar. Hal ini didukung dengan adanya semacam "potensi etos" yang dimiliki oleh pengrajin umumnya.

\begin{abstract}
IV
Sebagai suatu unit ekonomi rumahtangga, usaha kerajinan ukir-ukiran khas Toraja memiliki peranan yang cukup berarti sebagaimana dirasakan sendiri oleh para pengrajin, dalam upaya memenuhi kebutuhan hidup sehari-hari yang semakin meningkatbaik kuantitas maupun kualitasnya. Demikian pula mengenai keikutsertaan para pengrajin di dalam kegiatan sosial dan keagamaan serta kegiatan partisipasi pembangunan di lingkungan masing-masing, peluang-peluang untuk melakukan kegiatan-kegiatan tersebut sedikit banyak turut diciptakan oleh usaha kerajinan ukir-ukiran yang mereka tekuni di samping pekerjaan pokok mereka selaku petani.
\end{abstract}

Seberapa jauh peranan usaha kerajinan ukir-ukiran dalam meningkatkan pendapatan rumahtangga pengrajin, antara lain terungkap lewat hasil pemantauan pihak Kantor Departemen Perindustrian Kabupaten Tana Toraja yang mencatat bahwa nilai tambah yang diperoleh para pengrajin di Tana Toraja dalam tahun 1988 rata-rata Rp. 307.740,- setiap unit usaha dengan tenaga kerja rata-rata 3 orang, yakni anggota-anggota rumahtangga sendiri yang terdiri dari ayah, ibu dan anak.

Khusus di lokasi penelitian, nilai tambah yang diperoleh setiap rumahtangga pengrajin dalam satu tahun relatif sama dengan hasil pertanian mereka yang rata-rata hanya memperoleh hasil Rp. 350.000,- (satu tahun hanya sekali panen).

Dalam hal penyediaan lapangan kerja, peranan kerajinan ukir-ukiran antara lain ditunjukkan oleh hasil studi ini bahwa 26,46 $\%$ tenaga kerja produktif yang ada di lokasi penelitian terserap di dalam usaha kerajinan ukir-ukiran namun bila diperhitungkan dalam

No. 1 \& 2 Thn. I Juli / Desember 1990 
skala Kabupaten Tana Toraja hanya mencapai lebih $11 \%$ dari seluruh tenaga kerja yang terserap dalam sektor perindustrian.

Dalam bidang sosial, peranan kerajinan ukir-ukiran dapt ditelusuri lewat riwayat keberadaannya serta pada cirinya sebagai satuan usaha kecil/usaha rumahtangga.

Sejak awal keberadaannya, ukir-ukiran khas Tana Toraja telah membawa misi kehidupan berdasarkan kepercayaan dan falsafah yang melatarbelakanginya, yakni kepercayaan/falsafah Aluk Todolo. Missi yang dibawanya itu meliputi empat hal, yakni: (1) Sebagai dokumentasi dari falsafah kehidupan orang Toraja, (2) Sebagai dokumentasi dari peranan kesenian Toraja dalam pembinaan kehidupan masyarakat, (3) Sebagai lambang dari dasar-dasar kehidupan orang Toraja dalam pembinaan kehidupan masyarakat serta pola kehidupan sosial mereka, dan (4) Sebagai hiasan bangunan khas Toraja dalam kaitan dengan struktur masyarakatnya.

Missi simbolis dari ukir-ukiran khas Toraja tersebut masih dapat disaksikan secara langsung di daerah Tana Toraja dewasa ini antara lain dalam konteks seremonial seperti dalam upacara mcmbangun atau merenovasi rumah adat Tongkonan, juga dalam pelaksanaan upacara ritual Rambu Solo dan Rambu Tuka. Dalam pelaksanaan upacaraupacara tersebut, ukir-ukiran khas Toraja dengan ragam bias dan motif yang disesuaikan dengan konteks upacara selalu menghias bangunan-bangunan dan peralatan-peralatan upacara.

Dengan memahami kandungan makna yang disimbolkan oleh tiap-tiap bentuk dan motif ukir-ukiran khas Toraja maka para wisatawan, terutama wisatawan asing, bersedia membeli sepotong ruas bambu yang berukir dengan harga US\$ 5,00 sebagai cendera mata,

\section{No. 1 \& 2 Thn. I Juli / Desember 1990}

Dalam fungsinya selaku cendera mata, ukirukiran khas Toraja memainkan peranan selaku duta-duta masyarakat Toraja yang memperkenalkan kepada masyarakat dunia identitas sosio-kultural Toraja.

Dari segi cirinya sebagai satuan usaha kecil, ukiran khas Toraja banyak memainkan peranan sosial seperti antara lain penyediaan lapangan usaha dan penyerapan tenaga kerja di pedesaan, memberikan peluang untuk tumbuhnya kreativitas masyarakat, menumbuhkan dan mendorong kemampuan serta kemandirian berusaha di kalangan masyarakat. Peranan ini sesungguhnya merupakan kontribusi penting dari ukir-ukiran khas Toraja dalam pelaksanaan pembangunan.

Peranan lain dalam bidang pembangunan daerah ialah kontribusi produksi ukir-ukiran dalam meningkatkan volume pemasaran produksi daerah sekaligus meningkatkan nilai tambah dan secara tidak langsung menambah nilai ekspor. Dapat ditambahkan bahwa dari sejumlah 192.058 orang wisatawan yang mengunjungi daerah Tana Toraja dalam tahun 1988, diantaranya terdapat wisatawan asing sebanyak 22.108 orang. Jika diperhitungkan bahwa setiap wisatawan asing membelanjakan uangnya sebanyak rata-rata USS 7,00 untuk membeli barang kerajinan ukir-ukiran sebagai cendera mata, sementara untuk setiap wisatawan domestik diperkirakan membelanjakan uangnya untuk keperluan yang sama sebanyak rata-rata Rp.5000,- maka dalam tahun 1988 usaha kerajinan ukir-ukiran khas Toraja memberikan kontribusi peningkatan pengasilan daerah Toraja sebanyak Rp.1.120.573.000,atau lebih satu milyar rupiah, diantaranya Rp.270.823.000,- dalam bentuk nilai ekspor secara tidak langsung (diperhitungkan dari dollar yang dibelanjakan wisatawan asing untuk membeli ukir-ukiran sebagai cendera mata). 
Akan halnya peranan usaha kerajinan ukirukiran khas Toraja dalam bidang keagamaan, sesungguhnya peranan inilah yang merupakan missi utama kehadirannya. Dalam hal ini agama yang dimaksud ialah agama/kepercayaan Aluk Todolo yang merupakan kepercayaan asli orang Toraja. Empat missi atau fungsi dari kehadiran ukir-ukiran khas Toraja seperti telah dikemukakan, keseluruhannya bersumber dari ajaran kepercayaan Aluk Todolo. Dalam kaitan dengan ini wujud pe-ranan penting dari ukirukiran khas Toraja ialah secara simbolis berfungsi melestarikan ajaran-ajaran Aluk Todolo dalam hal nilai-nilai, norma-norma, dan etika kehidupan menurut ajaran kepercayaan ini. Makna yang disimbolkan itu dipercayai oleh penganut Aluk Todolo sebagai ajaran agama, sementara orang Toraja penganut agama lain (Kristen, Islam, dan Budha) menerima makna itu sebagai warisan leluhur yang mengandung nilai sosio-kultural yang tinggi dan karenanya perlu dilestarikan.

Selain makna simbolis, peranan usaha kerajinan ukir-ukiran khas Toraja dalam bidang sosial dan keagamaan dapat pula diunjukkan oleh nilai tambah materialnya; bahwa tambahan penghasilan yang diperoleh para pengrajin dari usaha kerajinan ukir-ukiran yang ditekuni selama ini memberikan peluang bagi mereka untuk dapat berperan dan berpartisipasi dalam kegiatan-kegiatan sosial dan keagamaan dalam lingkungan masyarakat masing-masing.

\section{V}

Demikianlah kerajinan ukir-ukiran kayu khas Toraja, sebagai unit ekonomi rumah tangga, dirasakan peranan/manfaatnya oleh para pengrajin, baik dalam upaya pemenuhan kebutuhan hidup mereka sehari-hari maupun di dalam melakukan partisipasi sosial dan keagamaan di lingkungan masyarakat masingmasing.

Namun demikian, kadar dan frekuensi dari peranan yang diberikan itu tentu saja sesuai dengan kondisi dan keberadaannya sebagai industri/kerajinan rumah tangga yang selama ini dianggap memiliki berbagai kelemahan.

Dalam rangka pembinaan industri kecil/ rumahtangga khusus kerajinan ukir-ukiran khas Toraja, sesuai dengan arah pembinaan yang diamanatkan GBHN, kebijaksanaan pembinaan seyogianya tidak sekedar ditujukan untuk mengatasi kelemahan-kelemahan yang dimiliki tetapi juga - dan terutama- ditujukan untuk mengembangkan "potensi etos" mereka yang justru menjadi pilar penopang eksistensi selama ini. 


\section{DAFTAR BACAAN}

Badrun, Pat., "Studi Tentang Kerukunan Hidup Umat Beragama di Tana Toraja". Makalah Ringkasan Laporan hasil Penelitian Balai Penelitian Lektur Keagamaan Ujung Pandang, disampaikan pada Seminar Intern BPLK Ujung Pandang, tanggal 15 Januari 1987.

Geertz, C, Penjaja dan Raja, Jakarta, Badan Penerbit Indonesia, 1973.

Kantor Departemen Perindustrian Kabupaten Tana Toraja, Laporan Tahunan 1988. Rantelemo.Makale, 1989.

Majelis Permusyawaratan Rakyat, Gar is-Gar is Besar aluan Negara 1988 TAP. No. II/MPR/1988, Solo, UD Mayasari, 1988.

Pakilaran, Aris, Prinsip Resiprositas dalam Masyarakat Toraja. Skripsi Sarjana Ilmu Antropologi, Ujung Pandang, FISIPOL UNHAS, 1987.
Raharjo, M. Dawam, Transformasi Pertanian Industrialisasi dan Kesempatan Kerja, Jakarta, Penerbit UT, 1984

Saleh, Irsan Azhary, Industri Kecil, Jakarta, LP3ES, 1986.

Sattu, Barto, Kerangka Pembangunan Strategis Kabupaten Daerah Tingkat II Tana Toraja Tahun 1985/1986 sampai 1989/1990, Makale, 1984

Tandilinting, L.T., Tongkonan (Rumah Adat Toraja) dengan Arsitektur \& Ragam hias, Ujung Pandang, Balai Kajian Sejarah dan nilai Tradisional Ujung Pandang, 1983.

Tandungan, Kristen, Industri Rumahtangga sebagai Unit Ekonomi di Kelurahan KaEro Kecamatan Sanggalangi Kabupaten Tana Toraja. Skripsi Sarjana Ilmu Antropologi, Ujung Pandang, FISIPOL UNHAS, 1987. 